\title{
EFFORTS TO IMPROVE SALTED FISH QUALITY USING ROTARY DRYING SYSTEM TECHNOLOGY IN GAMPONG KUALA LEUGE, PEUREULAK ACEH TIMUR
}

\author{
Najira*, Ica Veronika Maha, Titi Lestia Sriwahyuni, Nurfadillah, Nurul Kholiza Priani, Hayatul Nurul Fitri, \\ Ririn Mustika Ningrum, Marina Br. Sembiring, Mardudi, Maulina, Indah Piccaso Habinsaran and Danu \\ Abian latif. \\ Biology Education Study Program, Faculty of Teacher Training and Education, Samudra University, \\ Jln. Meurandeh, Langsa Lama District, Langsa City, Aceh Province, Indonesia \\ Email: najirapv10@gmail.com*
}

\begin{abstract}
Gampong Kuala Leuge, Peureulak District is one of the National Priority Rural Areas (KPPN) which has been designated as a Capture and Cultivation Minapolitan area by the Ministry of Marine Affairs and Fisheries because most of its people are fishermen. The conditions faced by the community regarding climate and weather, when the weather is hot, it is very easy to dry the fish, while in the rainy season generally, the salted fish will decrease. Thus, household scale competition also faces increasing competition in the digital age because people still use traditional tools and are very dependent on the climate. Therefore, in an effort to balance the competition it is necessary to increase the quality, productivity, and efficiency of the business by taking into account the aspects of food safety through the activities of the Village Development and Empowerment Holistic Program by creating a Rotary Drying System technology as a substitute for stocking to ensure the quality of fish and avoid contamination of microorganisms. From the problems obtained in the form of the dependence of the drying process on weather conditions so that salted fish products are not optimal, conventional marketing techniques have changed to modern ones by providing online shops, and financial management that has not been recorded properly has changed using digital transaction software.
\end{abstract}

Keywords: Salted Fish, Dryer, Rotary Drying Technology, Aceh 


\section{INTRODUCTION}

The richness of Indonesia's marine resources is very abundant, two-thirds of Indonesia's territory consists of the sea, fishery potential is estimated at 6,26 million tons/year with a variety of fish species and continues to increase, but not yet fully utilized. Estimtes of marine Fisheries production throughout April to june 2020 reach 1,6 milion tons. And Since the advent of the corona virus in Indonesia and other countries around the word, shrimp and brackish fish from marine farming have fallen from 20 to 30 persent (Ministry of Marine Fisheries and Fisheries Republic Of Indonesia. 2020)

Gampong Kuala Leuge, Peureulak District is one of the National Priority Rural Areas (KPPN) which has been designated as a Capture and Cultivation Minapolitan area by the Ministry of Marine Affairs and Fisheries because most of its people are fishermen (Urban Area Development Center. 2017). The fishermen's wife always processes the excess fish into salted fish as a form of utilization or reduction of fish waste and it becomes the daily work of fisherwomen there.

Drying fish management is one of the most widely used methods of preserving fish so that they are not wasted (Sudarma, T.F. 2017). In the drying process, there is a process of taking or decreasing water content to a certain extent so that it can slow down the rate of fish in biological and chemical activities. The basis for drying is the evaporation of water into the air due to the difference in water vapor content between the air and the dried material. In this case, the water vapor content in the air is less, or in other words, the air has lower water content so that it occurs. In evaporation, water is transferred in the form of steam at the boiling point while drying is usually in the form of steam and air.

Drying is usually the last step in the processing process prior to packaging, in order to produce more material suitable for storage. Therefore, drying is a relative meaning, namely the reduction of the moisture content contained in an initial value to an acceptable final value. The water content of the material varies depending on the purpose of drying the material, in addition to reducing the moisture content of the material, it measures the limits of the development of microorganisms and the activity of enzymes that cause spoilage in fish. Thus, the fish that are subjected to the drying process can be stored longer.

People generally dry the fish in the process of making salted fish using a traditional tool in the form of "Ancak" which is commonly known as a tray. the use of the tray cannot maximize the work of the local community, because people are very dependent on the weather and The risk to fish in this drying process is the decrease in the quality of the fish due to exposure to vehicle dust and microorganisms that can stick to the dried fish.

Based on the field survey, there is information obtained and it can be concluded that the pattern of people working as salted fish laborers is:

First, salted fish entrepreneurs carry out production activities, including management and trade. The raw material (fish) can come from local fishermen or collecting agents, then process the fish into salted fish and market it directly to traditional markets or too large traders (Directorate of Research, Community Service, Director General of Higher and Education Ministry of Edycation and Culture. 2013). Business groups are carried out individually or on a household scale. The production capacity on a household scale is $20-50 \mathrm{~kg} /$ day (Bank Indonesia, Director of Credit, BPR and UMKM. 2009). In this condition, the quality of salted fish in the market cannot be predicted because the sales value does not vary. The conditions faced by the community regarding climate and weather, when the weather is hot, it will be very easy to dry the fish, while in the rainy season generally, the salted fish will decrease. Therefore, Household-scale competition also faces increasing competition in the digital age because people still use traditional tools and are very dependent on the climate. Therefore, in an effort to balance the competition, it is necessary to increase the quality, productivity, and efficiency of the business by taking into account the aspects of food safety through the activities of the Village Development and Empowerment Holistic Program by making Rotary Drying System technology as a substitute for the stock to ensure the quality of fish and avoid contamination of microorganisms. 


\section{METHOD \\ Respondents \\ Approach}

Based on the problems that have been raised, this holistic village guidance and empowerment program uses the approach offered for the realization of a holistic village development and empowerment program, namely the interview method for people who feel the effectiveness of the rotary drying system technology with Instruments The preparation process for making tools that will be given to partners. The preparatory stage in making the rotary drying system Designed by a set of biological students from Samudra University, assisted by technical experts andincludes planning which has analyzed all the aspects needed to improve the quality of the fish, the capacity, and the price of the equipment needed.

\section{Procedures}

The initial study of the rotary drying system planning includes the heat needed to evaporate water, air flow rate, total heat and drying area, collector material, and collector angle so that it can absorb heat maximally according to the temperature required for the drying process of fish to become salted fish.

Business motivation, providing training in the form of motivation and management in business and various experiences with accompanying lecturers who have good experience in entrepreneurship so that they can foster enthusiasm in developing a business. The problems and business potentials developed by partners are business management training, this activity provides insight into the strategy of starting and developing a business, then more importantly training in the use of tools, providing training on how to operate, produce and maintain equipment. Community groups are fish laborers who live in Gampong Kuala Leuge, Peureulak District, East Aceh.

\section{FINDINGS AND DISCUSSION Tool Introduction}

From the problems obtained in the form of the dependence of the drying process on weather conditions so that salted fish products are not optimal, conventional marketing techniques have changed to modern ones by providing online shops, and financial management that has not been recorded properly has changed using digital transaction software. Through this service activity results have been obtained:

1. The community has operated a hygienic drying technique that reduces the spoilage of the fish.

2. Salted fish drying technology has been introduced which does not depend on climate and weather and also shortens the drying time of fish.

3. Using attractive packing so that it can increase product sales. 

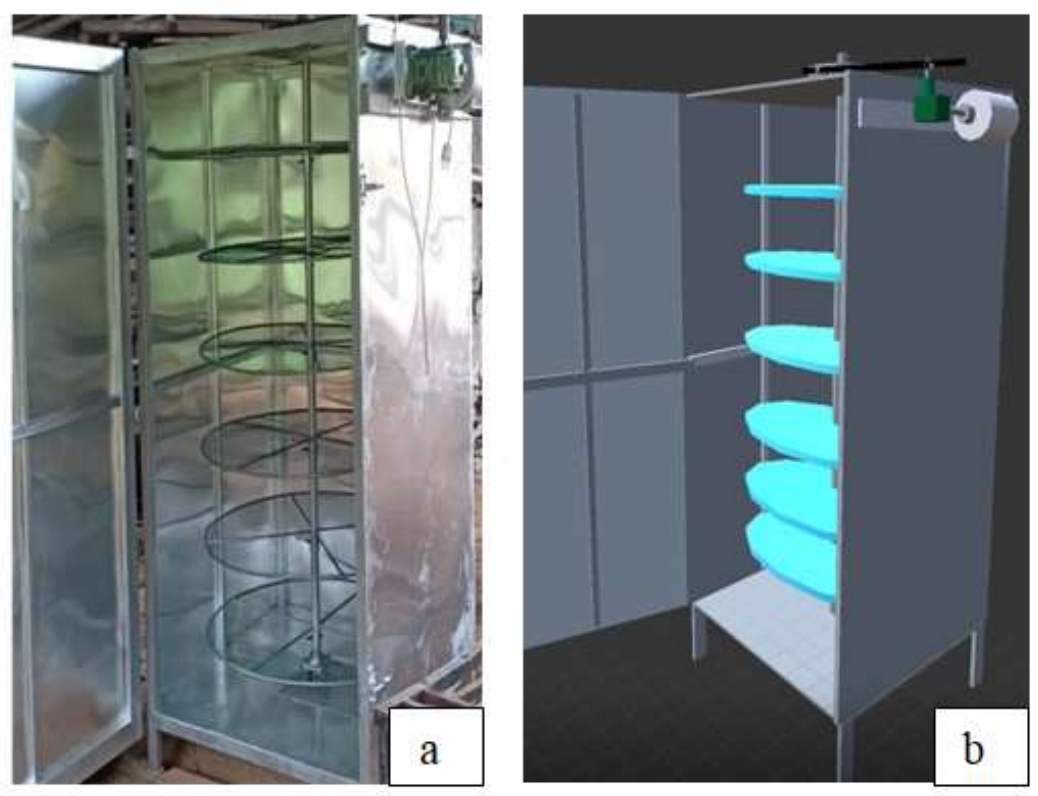

Picture 1. a. The inside of the rotary drying system

b. The design of the rotary drying system

\section{CONCLUSION}

From the holistic development and empowerment program activities of this village, it can be concluded that the knowledge and skills of hygienic salted fish production with the rotary drying system technology have been able to reduce production time in the drying process, partners have introduced rotary drying system technology to produce hygienic salted fish.

\section{ACKNOWLEDGEMENTS}

Thank you to Allah SWT for providing smoothness in the holistic village development and empowerment program activities, to the Ministry of education and culture, to the government and the Kuala Leuge village community who have participated and at the same time become partners in the holistic program of village development and empowerment.

\section{REFERENCES}

Bank Indonesia, Director of Credit, BPR dan UMKM. (2009). Small Business Financing Pattern (PPUK). Directorate of Research, Community Service, Director General of Higher and Education Ministry of Education and Culture. (2013). Research and community service in Higher Education edition IX.

Infrastructure Development Center PUPR Region III. (2017). Perchas Area and Peureulak national Priority (KPPN). http://perkotaan.bpiw.pu.go.id/v2/pendesaan. Accessed on 14 march 2021.

Ministry of Marine Fisheries and Fisheries Republic Of Indonesia. (2020). The Covid-19 Pandemic, The

Estimated Harvest Of Aquaculture Reaches 450 Thousand Tons Throughout April To June 2020. URL: https://kkp.go.id. Accessed on 14 march 2021.

Sudarma, T.F. (2017). Untilization Of Salted Fish Drying Mashine In An Effort To Reduce Poverty In Lvory Coast Village National Seminar On Community Service LPM Unimed. pp98-100. 